\title{
The Effect of Residential Environment on
}

\section{Respiratory Diseases and Pulmonary Function in Children from a Community in jilin Province of China}

This article was published in the following Dove Press journal:

Risk Management and Healthcare Policy

\author{
Changcong Wang' \\ Yangming Qu' \\ Huikun Niu' \\ Yingan Pan' \\ Yinghua $\mathrm{He}^{2}$ \\ Jianwei Liu \\ Nan Yao' \\ Han Wang' \\ Yinpei Guo' \\ Yang $\operatorname{Pan}^{2,3}$ \\ Bo $\mathrm{Li}^{1}{ }^{1}$ \\ 'Department of Epidemiology and \\ Biostatistics, School of Public Health, Jilin \\ University, Changchun, Jilin, I3002 I, \\ People's Republic of China; ${ }^{2}$ jilin \\ Provincial Center for Disease Control \\ and Prevention, Changchun, Jilin, I30062, \\ People's Republic of China; ${ }^{3}$ Department \\ of Occupational and Environmental \\ Health, School of Public Health, jilin \\ University, Changchun, I3002I, People's \\ Republic of China
}

Correspondence: Bo Li

Department of Epidemiology and Biostatistics, Jilin University School of

Public Health, II 63 Xinmin Street,

Changchun, Jilin, I3002I, People's

Republic of China

$\mathrm{Tel} / \mathrm{Fax}+86$ 43 I8561945|

Email li_bo@jlu.edu.cn

Yang Pan

Jilin Provincial Center for Disease

Control and Prevention, Changchun, Jilin,

130062, People's Republic of China

Tel +86 I8844504063

Email18844504063@I63.com
Purpose: Respiratory disease is a major and increasingly global epidemic that has a great impact on humans, especially children. The purpose of this study was to identify environmental risk factors for respiratory diseases and pulmonary function in children.

Patients and Methods: A population-based, cross-sectional survey of respiratory diseases and environmental risk factors was conducted in Jilin Province, China. Complete questionnaire information was available for 2419 children, while adequate pulmonary function data were available for a subgroup of 627 children.

Results: Our study found that environmental risk factors for respiratory health in children were mainly concentrated indoors. After adjusting for demographic factors, insecticide exposure and passive smoking were risk factors for respiratory disease and industrial pollutant sources, insecticide exposure and the use of a fume exhauster may be independent risk factors for recurrent respiratory infections. The main fuel for cooking in the winter and passive smoking were the main influencing factors of pulmonary function indicators.

Conclusion: The primary risk factors differ in different respiratory diseases. Passive smoking remains a critical adverse factor for respiratory illness and pulmonary function in children, and it is important to reduce children's exposure to passive smoking to increase pulmonary health. Insecticide exposure may be a neglected environmental risk factor, and further investigations are still needed to explore the relationship and mechanisms between insecticide exposure and children's respiratory health.

Keywords: respiratory diseases, lung function, environmental risk factors

\section{Introduction}

Environmental factors play an essential role in the health and development of children. A safe and healthy environment contributes to children's growth and health but is absent in some countries. ${ }^{1}$ According to reports, environmental risk factors remain a major risk factor affecting children's health, causing various shortand long-term damage to children. ${ }^{2}$ Meanwhile, poor health among children places a financial strain on the children's families, in terms of medical costs, and the national public health care systems. ${ }^{3,4}$ It is worth noting that respiratory diseases are a major cause of poor health in children.

Pulmonary development and function can be easily altered by early exposure to environmental risk factors in children, whose lungs are still growing and 
developing. Environmental risk factors might have adverse effects on children's respiratory system, leading to a decline in lung function. ${ }^{5,6}$ For example, exposure to traffic pollutants may cause children coughing, sneezing, asthma, and decreased lung function in children. ${ }^{7-11}$ Concurrently, phthalates, pesticides, and bisphenol-A (BPA) are known to be important risk factors for the development and exacerbation of asthma. ${ }^{12,13}$ In addition, environmental tobacco smoke (ETS), air pollution and the family environment may be associated with respiratory infection. $^{14-16}$ Notably, ETS exposure may cause an increase in symptoms of respiratory disease. ${ }^{17,18}$ To date, the effects of some environmental factors on the respiratory system of children have been demonstrated. For example, passive smoking is considered a risk factor for many respiratory diseases, such as asthma and rhinallergosis. ${ }^{19,20}$ However, except for passive smoking, there is still limited research on the impact of environmental risk factors in the living environment on respiratory diseases. We examined associations between environmental risk factors in the living environment and children's respiratory health, as assessed by a questionnaire and pulmonary function measurements, in a cross-sectional study of a predominantly Chinese community in Jilin Province, China.

\section{Patients and Methods}

\section{Study Population}

Considering the regional characteristics of air pollution and ethnic minorities, we chose Changchun, the provincial capital city, and Yanji, a minority gathering area, as the study cities. In each city, two primary schools were randomly selected, and at least 200 students each from grades 3 rd through 5 th were selected using the cluster random sampling method in October 2016. We assessed the impact of environmental factors on respiratory health in children $(n=2419)$.

\section{Exposure Assessment}

The environmental impact factors were assessed through the parental questionnaire. The parental questionnaire was based on a review of the literature and designed to identify the demographic information and environmental factors to be assessed. The questionnaire was further refined by a presurvey, and it was developed jointly by epidemiologists and environmental health experts. Trained investigators applied the questionnaire, and the main environmental variables were as follows. Outdoor environmental exposures: industrial pollutant sources (exposure to garbage stations, foul ditches, heating companies or noise with 100 meters around home); and distance from home to main traffic roads $(<20 \mathrm{~m}$, 20-150 m, >150 m). Indoor environmental exposures: insecticide exposure (exposure to insecticides, anophelifuges or moth repellant); other organic solvent exposure (exposure to air fresheners or disinfectants); indoor furnishings (decorated the house within three years or bought new furniture within a year); presence or absence of pets; passive smoking (smoke inhaled every day for more than 15 minutes); (No, <1 day/week, 1-2 day/ week, $>2$ days/week); main heating mode (central heating, household gas heating, heating via spontaneous combustion of coal, others); main fuel used for cooking (electric power, natural gas, liquid gas, pipeline gas, others); and use of a fume exhauster or air cleaner. Moreover, information about the frequency of opening the windows in winter (No, 1-3 times/week, $>3$ times/ week) was collected.

\section{Health Outcome Assessment}

Children's health outcomes included recurrent respiratory tract infection, pneumonia, asthma, tracheitis/bronchitis and rhinallergosis; these outcomes were also ascertained by the parental questionnaire. The main outcome, respiratory disease, was defined as at least one of the following: recurrent respiratory tract infections, pneumonia, asthma, tracheitis/bronchitis or rhinallergosis. All diseases were clinically confirmed and had a clear diagnosis report. Limited funds were available to select $25 \%$ of the primary school students for assessment of pulmonary function. In each school, at least 50 primary school students from grades 3 to 5 were randomly selected for pulmonary function testing in each grade (generally one class as a whole using the cluster random sampling method); in principle, both sexes were equally represented. A subset of the selected study population underwent analysis of pulmonary function (Chestgraph HI-101, Japan) at a designated hospital or medical examination center after the children's weight and standing height were obtained $(n=627)$. The pulmonary function analysis included forced vital capacity (FVC), forced expiratory volume in 1 second $\left(\mathrm{FEV}_{1}\right)$, $\mathrm{FEV}_{1} / \mathrm{FVC}$, peak expiratory flow velocity (PEF), forced expiratory flow at $25 \% \mathrm{FVC}\left(\mathrm{V}_{25}\right)$ and forced expiratory flow at $75 \% \mathrm{FVC}\left(\mathrm{V}_{75}\right)$. 


\section{Ethics Statement}

This study was conducted in accordance with the Declaration of Helsinki. The Ethics Committee of Jilin Provincial Center for Disease Control and Prevention approved this study, and informed consent was obtained from all pupils and parents before the study was conducted. Written informed consent from the parents was obtained for each participant.

\section{Quality Control}

All investigators were trained before the investigation. Reviewers examined the questionnaires on the same day that they were completed (to check whether the questionnaire was completed and whether there were logical errors); if necessary, unqualified questionnaires were corrected, and omissions eventually completed by contacting the investigator or the subjects. The data were double-entered in parallel and corrected according to the consistency test report. The measurement instruments for pulmonary function assessment were calibrated according to the same standard provided in the CHESTGRAPH HI-101 User's Manual.

\section{Statistical Analysis}

The database was established by EpiData 3.1, and statistical analysis was carried out using SPSS 17.0 and $\mathrm{R}$ version 3.6.2 statistical software. Categorical variables are described as numbers and frequencies, and continuous variables are described as $\overline{\mathrm{x}} \pm \mathrm{s}$ (mean \pm standard deviation). The $\chi^{2}$ test and $t$-test were adopted for comparisons between two groups. The least significant difference (LSD) procedure and one-way ANOVA were used to compare the means of three groups. To analyze the environmental risk factors for respiratory diseases and pulmonary function, we used multivariate logistic regression analysis and stepwise multiple linear regression analysis. In addition, different models were constructed by adjusting for demographic variables. A $P$-value $<0.05$ (two-tailed) was considered to be statistically significant.

\section{Results}

\section{Characteristics of the Study Population}

A total of 2419 subjects were included in the study, and the characteristics of the study population are listed in Table 1. The sex ratio of the study population was close to 1. The educational background of most children's parents was junior high school or above. The prevalence of respiratory diseases was $14.8 \%$, and the prevalence of the five different respiratory diseases evaluated was $6.2 \%$ for recurrent respiratory tract infection, $1.1 \%$ for pneumonia, $0.9 \%$ for asthma, $4.4 \%$ for tracheitis/bronchitis, and $4.9 \%$ for rhinallergosis (Table 2). Almost all families used a fume exhauster during cooking, nearly half of the households used natural gas, and some families were exposed to other environmental factors (Table 1). There were few differences between the pulmonary function testing subset and the larger study sample in selected demographics, health outcomes, and environmental exposures $(P>0.05)$. Therefore, the subset can reasonably represent the study population.

\section{Univariate Analysis of the Environmental Risk Factors for Respiratory Diseases}

Significant differences were found in industrial pollutant sources, insecticide exposure, other organic solvents and passive smoking between the population with respiratory diseases and the population without respiratory diseases $(P<0.05)$ (Table S1). In the four respiratory diseases other than pneumonia, insecticide exposure and passive smoking were significantly different between those with and without disease. The distribution of the main fuel for cooking in winter was significantly different only between those with and without pneumonia. Other detailed univariate analysis results are shown in Table S2.

\section{Multivariable Analysis of the Environmental Risk Factors for Respiratory Diseases}

Taking respiratory diseases as the dependent variables, the significant factors in the univariate analysis (industrial pollutant sources, insecticide exposure, other organic solvents and passive smoking) were entered as the independent variables, and multivariate logistic regression was conducted to analyze the environmental risk factors for respiratory diseases. The valuation of variables is listed in Table S3.

As shown in Figure 1, exposure to industrial sources of pollutants, pesticides, other organic solvents, and passive smoking were risk factors for respiratory disease in model 1 (unadjusted) and model 2 (adjusted for sex and highest parental education). After adjusting for sex, parental education, allergic history, past history of respiratory diseases and family history of respiratory diseases, only insecticide exposure and passive smoking were risk factors for respiratory disease $(P<0.05)$. 
Table I Characteristics of Study Population [n(\%)]

\begin{tabular}{|c|c|c|c|c|c|}
\hline \multicolumn{2}{|l|}{ Factors } & $\begin{array}{l}\text { Study Population } \\
(n=24 \mid 9)\end{array}$ & $\begin{array}{l}\text { Subset } \\
(n=627)\end{array}$ & $\chi^{2}$ & $P$ \\
\hline \multicolumn{6}{|l|}{ Demographics } \\
\hline Sex & $\begin{array}{l}\text { Female } \\
\text { Male }\end{array}$ & $\begin{array}{l}\text { II } 25(46.5) \\
1294(53.5)\end{array}$ & $\begin{array}{l}293(46.7) \\
334(53.3)\end{array}$ & 0.010 & 0.920 \\
\hline Father's highest degree & $\begin{array}{l}\text { Primary school and below } \\
\text { Junior middle school } \\
\text { High school } \\
\text { College degree } \\
\text { Bachelor or above }\end{array}$ & $\begin{array}{l}118(4.9) \\
706(29.2) \\
709(29.3) \\
47 \mid(19.5) \\
415(17.2)\end{array}$ & $\begin{array}{l}22(3.5) \\
158(25.2) \\
196(31.3) \\
144(23) \\
107(17.1)\end{array}$ & 8.474 & 0.076 \\
\hline Mother's highest degree & $\begin{array}{l}\text { Primary school and below } \\
\text { Junior middle school } \\
\text { High school } \\
\text { College degree } \\
\text { Bachelor or above }\end{array}$ & $\begin{array}{l}137(5.7) \\
756(31.3) \\
670(27.7) \\
462(19.1) \\
394(16.3)\end{array}$ & $\begin{array}{l}26(4.1) \\
181(28.9) \\
178(28.4) \\
133(21.2) \\
109(17.4)\end{array}$ & 4.648 & 0.325 \\
\hline Respiratory diseases & $\begin{array}{l}\text { No } \\
\text { Yes }\end{array}$ & $\begin{array}{l}2060(85.2) \\
359(14.8)\end{array}$ & $\begin{array}{l}543(86.6) \\
84(13.4)\end{array}$ & 0.835 & 0.361 \\
\hline Allergic history & $\begin{array}{l}\text { No } \\
\text { Yes }\end{array}$ & $\begin{array}{l}2089(86.4) \\
330(13.6)\end{array}$ & $\begin{array}{l}530(84.5) \\
97(15.5)\end{array}$ & 1.381 & 0.240 \\
\hline Past history of respiratory diseases & $\begin{array}{l}\text { No } \\
\text { Yes }\end{array}$ & $\begin{array}{l}2049(84.7) \\
370(15.3)\end{array}$ & $\begin{array}{l}535(85.3) \\
92(14.7)\end{array}$ & 0.150 & 0.699 \\
\hline $\begin{array}{l}\text { Family history of respiratory } \\
\text { diseases }\end{array}$ & $\begin{array}{l}\text { No } \\
\text { Yes }\end{array}$ & $\begin{array}{l}2308(95.4) \\
111(4.6)\end{array}$ & $\begin{array}{l}603(96.2) \\
24(3.8)\end{array}$ & 0.681 & 0.409 \\
\hline \multicolumn{6}{|l|}{ Outdoor environmental exposures } \\
\hline $\begin{array}{l}\text { Distance from home to main traffic } \\
\text { road }\end{array}$ & $\begin{array}{l}<20 \mathrm{~m} \\
20-150 \mathrm{~m} \\
>150 \mathrm{~m}\end{array}$ & $\begin{array}{l}377(15.6) \\
992(41) \\
1050(43.4)\end{array}$ & $\begin{array}{l}103(16.4) \\
263(41.9) \\
261(41.6)\end{array}$ & 0.697 & 0.706 \\
\hline Industrial pollutant sources & $\begin{array}{l}\text { No } \\
\text { Yes }\end{array}$ & $\begin{array}{l}1533(63.4) \\
886(36.6)\end{array}$ & $\begin{array}{l}385(6 I .4) \\
242(38.6)\end{array}$ & 0.829 & 0.363 \\
\hline \multicolumn{6}{|l|}{ Indoor environmental exposures } \\
\hline Insecticide exposure & $\begin{array}{l}\text { No } \\
\text { Yes }\end{array}$ & $\begin{array}{l}2100(86.8) \\
319(13.2)\end{array}$ & $\begin{array}{l}542(86.4) \\
85(13.6)\end{array}$ & 0.059 & 0.808 \\
\hline Other organic solvent exposure & $\begin{array}{l}\text { No } \\
\text { Yes }\end{array}$ & $\begin{array}{l}2028(83.8) \\
391(16.2)\end{array}$ & $\begin{array}{l}512(81.7) \\
115(18.3)\end{array}$ & 1.705 & 0.192 \\
\hline Indoor furnishings & $\begin{array}{l}\text { No } \\
\text { Yes }\end{array}$ & $\begin{array}{l}1989(82.2) \\
430(17.8)\end{array}$ & $\begin{array}{l}517(82.5) \\
110(17.5)\end{array}$ & 0.018 & 0.892 \\
\hline Pet & $\begin{array}{l}\text { No } \\
\text { Yes }\end{array}$ & $\begin{array}{l}2181(90.2) \\
238(9.8)\end{array}$ & $\begin{array}{l}567(90.4) \\
60(9.6)\end{array}$ & 0.041 & 0.840 \\
\hline Window opening in winter & $\begin{array}{l}\text { No } \\
\text { I-3 times/week } \\
\text { >3 times/week }\end{array}$ & $\begin{array}{l}218(9) \\
856(35.4) \\
1345(55.6)\end{array}$ & $\begin{array}{l}60(9.6) \\
221(35.2) \\
346(55.2)\end{array}$ & 0.188 & 0.910 \\
\hline
\end{tabular}

(Continued) 
Table I (Continued).

\begin{tabular}{|c|c|c|c|c|c|}
\hline \multicolumn{2}{|l|}{ Factors } & \multirow{2}{*}{$\begin{array}{l}\text { Study Population } \\
(n=24 \mid 9)\end{array}$} & \multirow{2}{*}{$\begin{array}{l}\begin{array}{l}\text { Subset } \\
(n=627)\end{array} \\
530(84.5) \\
45(7.2) \\
24(3.8) \\
28(4.5)\end{array}$} & \multirow{2}{*}{$\begin{array}{l}\chi^{2} \\
.025\end{array}$} & \multirow{2}{*}{$\begin{array}{l}P \\
0.795\end{array}$} \\
\hline Passive smoking & $\begin{array}{l}\text { No } \\
<1 \text { day/week } \\
\text { I-2 day/week } \\
>2 \text { day/week }\end{array}$ & & & & \\
\hline Main heating mode & $\begin{array}{l}\text { Central heating } \\
\text { Household gas heating } \\
\text { Heating of spontaneous combustion } \\
\text { coal } \\
\text { Others }\end{array}$ & $\begin{array}{l}2198(90.9) \\
82(3.4) \\
89(3.7) \\
50(2.1)\end{array}$ & $\begin{array}{l}565(90.1) \\
19(3) \\
21(3.3) \\
22(3.5)\end{array}$ & 4.754 & 0.191 \\
\hline The main fuel for cooking in winter & $\begin{array}{l}\text { Electric power } \\
\text { Natural gas } \\
\text { Liquid gas } \\
\text { Pipe-line gas } \\
\text { Others }\end{array}$ & $\begin{array}{l}247(10.2) \\
1039(43) \\
700(28.9) \\
384(15.9) \\
49(2)\end{array}$ & $\begin{array}{l}57(9.1) \\
286(45.6) \\
190(30.3) \\
84(13.4) \\
10(1.6)\end{array}$ & 4.221 & 0.377 \\
\hline Fume exhauster & $\begin{array}{l}\text { No } \\
\text { Yes }\end{array}$ & $\begin{array}{l}162(6.7) \\
2257(93.3)\end{array}$ & $\begin{array}{l}40(6.4) \\
587(93.6)\end{array}$ & $0.08 \mathrm{I}$ & 0.776 \\
\hline Air cleaner & $\begin{array}{l}\text { No } \\
\text { Yes }\end{array}$ & $\begin{array}{l}2105(87) \\
314(13)\end{array}$ & $\begin{array}{l}536(85.5) \\
91(14.5)\end{array}$ & 1.015 & 0.314 \\
\hline
\end{tabular}

Table 2 The Prevalence of the Different Respiratory/Allergic Diseases

\begin{tabular}{|l|l|l|}
\hline Respiratory Diseases & Yes [n(\%)] & No [n(\%)] \\
\hline Recurrent respiratory tract infection & $151(6.2)$ & $2268(93.8)$ \\
\hline Pneumonia & $27(1.1)$ & $2392(98.9)$ \\
\hline Asthma & $22(0.9)$ & $2397(99.1)$ \\
\hline Tracheitis/ bronchitis & $107(4.4)$ & $2312(95.6)$ \\
\hline Rhinallergosis & $119(4.9)$ & $2300(95.1)$ \\
\hline
\end{tabular}

In addition, we performed individual multivariate analyses for the five different respiratory/allergic diseases. After adjusting for demographic factors, we found that passive smoking may be an independent risk factor for tracheitis/bronchitis and rhinallergosis, and industrial pollutant sources, insecticide exposure, and the use of a fume exhauster may be independent risk factors for recurrent respiratory infections. No environmental risk factors were found for pneumonia or asthma (Figure 2).

\section{Pulmonary Function Under Different Environmental Conditions}

As shown in Table S4, the FVC of children whose homes were $>150 \mathrm{~m}$ from the main traffic road was significantly lower than those whose homes were $<20 \mathrm{~m}$ from the main traffic road $(P<0.05)$. Compared to children whose homes were $>150 \mathrm{~m}$ from the main traffic road, children whose homes were $<20 \mathrm{~m}$ and $20-150 \mathrm{~m}$ from the main traffic road had lower $\mathrm{FEV}_{1} / \mathrm{FVC}$. The $\mathrm{V}_{25}$ of children whose homes had windows open in winter $>3$ times/week was significantly higher than that among children whose windows were open $1-3$ times/week $(P<0.05)$. FVC values were all significantly different among children exposed to passive smoking $<1$ day/week, passive smoking 1-2 day/ week and no passive smoking $(P<0.05)$; the $\mathrm{FEV}_{1}$ among children exposed to passive smoking 1-2 day/week was lower than that among children who were not exposed to passive smoking $(P<0.05)$; The $\mathrm{FVC}, \mathrm{FEV}_{1}$ and $\mathrm{V}_{75}$ values for children exposed to electric power, liquid gas and pipeline gas were all higher than those for children 


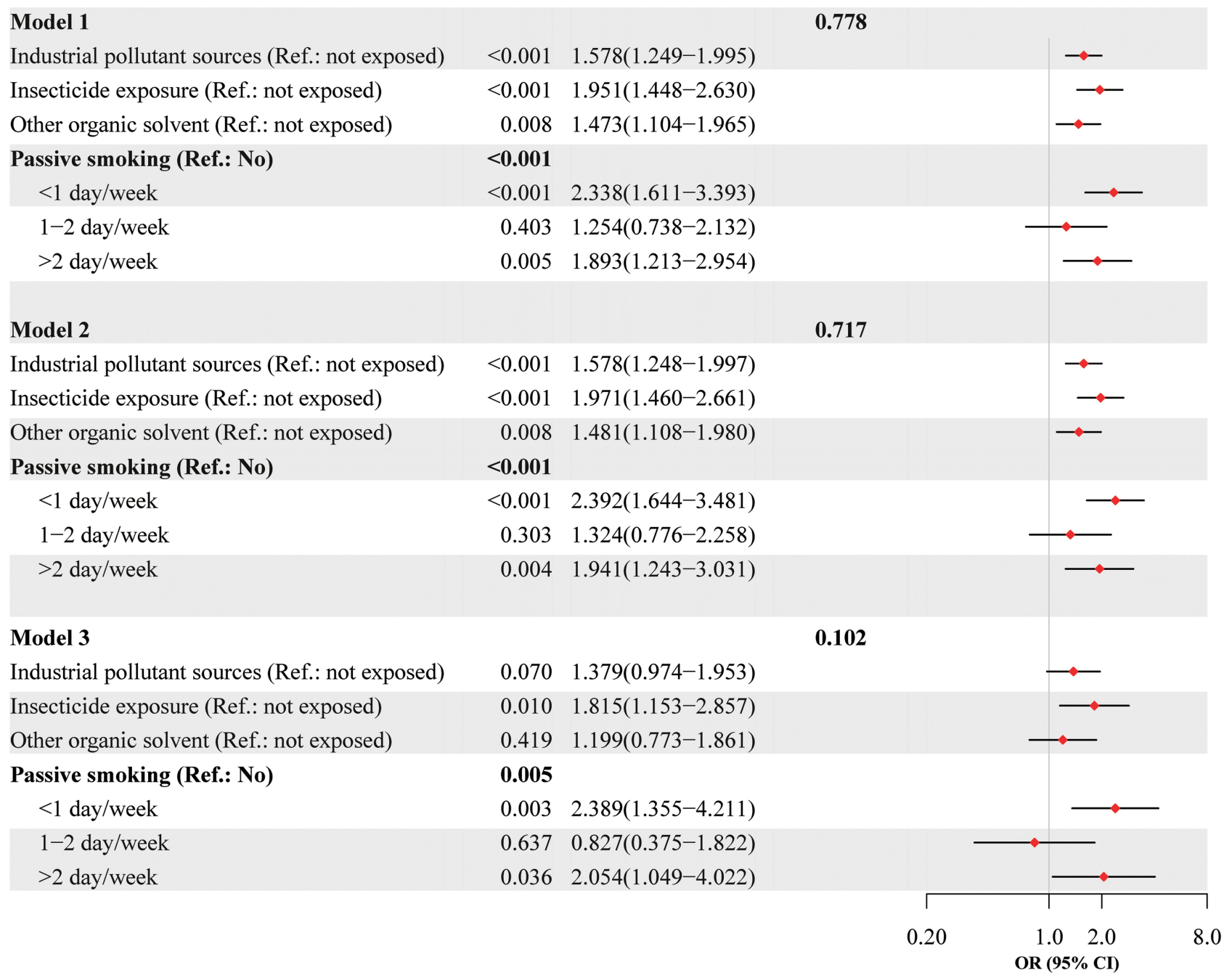

Figure I Multivariable analysis of the environmental risk factors for respiratory diseases.

Notes: Model I: unadjusted; Model 2: adjusted for sex, father's highest degree and mother's highest degree; Model 3: adjusted for sex, father's highest degree, mother's highest degree, allergic history, past history of respiratory diseases and family history of respiratory diseases.

Abbreviations: HL Test, Hosmer and Lemeshow Test; OR, odds ratio; $\mathrm{Cl}$, confidence interval.

exposed to natural gas, while the opposite was true for $\mathrm{FEV}_{1} / \mathrm{FVC}(P<0.05)$.

\section{Stepwise Multiple Linear Regression Analysis of Pulmonary Function Indicators}

As shown in Table 3, the potential environmental impact factors differed for different pulmonary function indicators. The main fuel used for cooking in winter affected $\mathrm{FEV}_{1} / \mathrm{FVC}, \mathrm{FVC}$ and $\mathrm{FEV}_{1}$ in children. In addition, FVC and $\mathrm{FEV}_{1}$ might be influenced by passive smoking; the distance from home to the main road also influenced $\mathrm{FEV}_{1}$ /FVC and FVC in children; and window opening in winter impacted children's $V_{25}$. Lower $V_{25}$ was seen with a high frequency of window openings per week. After adjusting for demographic factors, no environmental variables significantly affected PEF in our current study.

\section{Discussion}

The use of questionnaires allowed us to collect and analyze information on children's respiratory health and their living environment easily, quickly, efficiently and economically. The aim of this study was to investigate some environmental risk factors for respiratory diseases and lung function through the analysis of children's indoor 


\section{Variables}

Recurrent respiratory tract infection

Industrial pollutant sources (Ref.: not exposed)

Insecticide exposure (Ref.: not exposed)

Other organic solvent (Ref.: not exposed)

Passive smoking (Ref.: No)

$$
\begin{aligned}
& <1 \text { day/week } \\
& 1-2 \text { day/week } \\
& >2 \text { day/week }
\end{aligned}
$$

Fume exhauster (Ref.: not exposed)

\section{Pneumonia}

The main fuel for cooking in winter (Ref.: Electric power)

Natural gas

Liquid gas

Pipe-line gas

others

Air cleaner (Ref.: not exposed)

\section{Asthma}

Insecticide exposure (Ref.: not exposed)

Passive smoking (Ref.: No)

$<1$ day/week

1-2 day/week

$>2$ day/week

Air cleaner (Ref.: not exposed)

Tracheitis/ bronchitis

Insecticide exposure (Ref.: not exposed)

Other organic solvent (Ref.: not exposed)

Passive smoking (Ref.: No)

$<1$ day/week

1-2 day/week

$>2$ day/week

Rhinallergosis

Industrial pollutant sources (Ref.: not exposed)

Distance from home to main traffic road (Ref.: No $<20 \mathrm{~m}$ )

$$
\begin{aligned}
& 20-150 \mathrm{~m} \\
& >150 \mathrm{~m}
\end{aligned}
$$

Insecticide exposure (Ref.: not exposed)

Other organic solvent (Ref.: not exposed)

Passive smoking (Ref.: No)

$$
\begin{aligned}
& <1 \text { day/week } \\
& 1-2 \text { day/week } \\
& >2 \text { day/week }
\end{aligned}
$$

P for AOR

$\begin{array}{rr}<0.001 & 2.054(1.382-3.055) \\ 0.025 & 1.724(1.072-2.775) \\ 0.506 & 0.846(0.518-1.384) \\ 0.310 & \\ 0.232 & 1.465(0.783-2.741) \\ 0.260 & 1.573(0.715-3.464) \\ 0.212 & 1.604(0.763-3.371) \\ 0.013 & 4.222(1.357-13.139)\end{array}$

0.065

0.764

0.072

0.072

0.107

0.394

0.056

0.132

0.225

0.051

0.793

0.720

0.091

0.814

0.102

0.115

0.036

0.907

0.293

0.209

0.032

0.535

0.175

0.923

0.373

0.035

0.339

0.356

0.013

0.835(0.257-2.711)

$0.259(0.059-1.129)$

$0.157(0.017-1.494)$

$2.456(0.311-19.413)$

2.591(0.978-6.868)

$2.128(0.796-5.689)$

2.983(0.998-8.919)

$0.753(0.090-6.278)$

$0.658(0.067-6.506)$

2.391(0.870-6.572)

$1.068(0.616-1.850)$

1.541(0.918-2.585)

$1.990(1.044-3.790)$

1.058(0.412-2.718)

0.583(0.214-1.592)

$1.330(0.852-2.076)$

$1.212(0.660-2.227)$

$0.644(0.341-1.217)$

$0.973(0.557-1.698)$

1.269(0.751-2.143)

$0.681(0.310-1.496)$

$0.608(0.212-1.749)$

2.560(1.224-5.354)
95\% CI for AOR P for HL Test

\subsection{2}

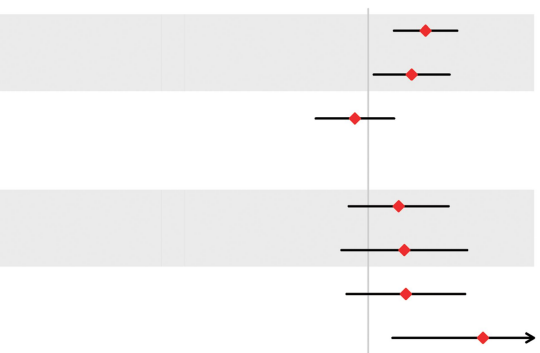

0.837
0.444

0.689

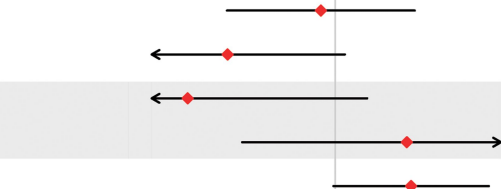

0.095
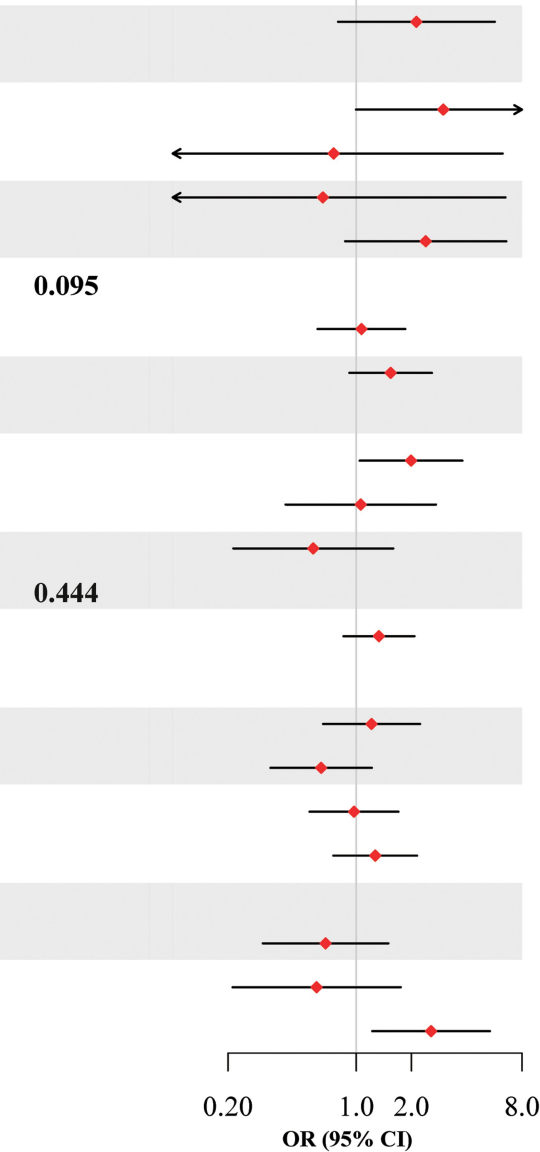

Figure 2 Multivariable analysis of the environmental risk factors for five respiratory diseases. Adjusted for sex, father's highest degree, mother's highest degree, allergic history, past history of respiratory diseases and family history of respiratory diseases.

Abbreviations: $\mathrm{HL}$ Test, Hosmer and Lemeshow Test; AOR, adjusted odds ratio; $\mathrm{Cl}$, confidence interval.

and outdoor environments by using a questionnaire. The respiratory health effect of environmental smoke exposure is an important issue worldwide. We found that passive smoking could influence respiratory disease and lung function in children, even after adjusting for demographic factors. The analysis of five different respiratory diseases showed that the environmental risk factors also differed among the different respiratory diseases. In addition, the 
Table 3 Stepwise Multiple Linear Regression Analysis for Pulmonary Function Indices in the Subset Population $(n=627)$

\begin{tabular}{|c|c|c|c|c|c|c|}
\hline \multicolumn{2}{|c|}{ Variables and Model } & \multirow{4}{*}{$\begin{array}{c}\text { SE } \\
0.003 \\
0.003\end{array}$} & \multirow{4}{*}{$\begin{array}{c}\boldsymbol{\beta} \\
0.111 \\
-0.086\end{array}$} & \multirow{4}{*}{$\begin{array}{c}P \\
0.005 \\
0.031\end{array}$} & \multirow{4}{*}{$\begin{array}{l}\text { VIF } \\
1.001 \\
1.001\end{array}$} & \multirow{4}{*}{$\frac{\text { Durbin-Watson }}{1.872}$} \\
\hline \multirow[t]{6}{*}{ FEV $/$ FVC } & Model I & & & & & \\
\hline & Distance from home to main traffic road (Ref.: $<20 \mathrm{~m})$ & & & & & \\
\hline & The main fuel for cooking in winter (Ref.: Electric power) & & & & & \\
\hline & Model 2 & & & & & 1.870 \\
\hline & Distance from home to main traffic road (Ref.: $<20 \mathrm{~m})$ & 0.003 & 0.110 & 0.006 & 1.008 & \\
\hline & The main fuel for cooking in winter (Ref.: Electric power) & 0.003 & -0.085 & 0.033 & 1.007 & \\
\hline \multirow[t]{8}{*}{ FVC } & Model I & & & & & 1.931 \\
\hline & Distance from home to main traffic road (Ref.: $<20 \mathrm{~m})$ & 0.028 & -0.094 & 0.017 & 1.006 & \\
\hline & Passive smoking (Ref.: not exposed) & 0.027 & -0.104 & 0.009 & 1.013 & \\
\hline & The main fuel for cooking in winter (Ref.: Electric power) & 0.022 & $0.13 \mid$ & 0.001 & 1.009 & \\
\hline & Model 2 & & & & & 1.914 \\
\hline & Distance from home to main traffic road (Ref.: $<20 \mathrm{~m})$ & 0.027 & -0.082 & 0.034 & 1.014 & \\
\hline & Passive smoking (Ref.: not exposed) & 0.027 & -0.115 & 0.004 & 1.045 & \\
\hline & The main fuel for cooking in winter (Ref.: Electric power) & 0.022 & 0.128 & 0.001 & 1.014 & \\
\hline \multirow[t]{6}{*}{ FEV } & Model I & & & & & 1.942 \\
\hline & Passive smoking (Ref.: not exposed) & 0.023 & -0.100 & 0.012 & 1.008 & \\
\hline & The main fuel for cooking in winter (Ref.: Electric power) & 0.019 & 0.130 & 0.001 & 1.008 & \\
\hline & Model 2 & & & & & 1.937 \\
\hline & Passive smoking (Ref.: not exposed) & 0.023 & -0.113 & 0.004 & 1.039 & \\
\hline & The main fuel for cooking in winter (Ref.: Electric power) & 0.019 & 0.127 & 0.001 & 1.013 & \\
\hline \multirow[t]{4}{*}{ PEF } & Model I & & & & & 2.083 \\
\hline & Window opening in winter (Ref.: $>3$ times/week) & 0.047 & -0.081 & 0.044 & 1.000 & \\
\hline & Model 2 & & & & & 2.072 \\
\hline & Window opening in winter (Ref.: $>3$ times/week) & 0.047 & -0.068 & 0.088 & 1.028 & \\
\hline \multirow[t]{4}{*}{$\mathbf{V}_{75}$} & Model I & & & & & 1.988 \\
\hline & The main fuel for cooking in winter (Ref.: Electric power) & 0.027 & 0.091 & 0.023 & 1.000 & \\
\hline & Model 2 & & & & & 1.990 \\
\hline & The main fuel for cooking in winter (Ref.: Electric power) & 0.027 & 0.087 & 0.029 & 1.006 & \\
\hline \multirow[t]{4}{*}{$\mathbf{V}_{25}$} & Model I & & & & & 2.132 \\
\hline & Window opening in winter (Ref.: No) & 0.048 & -0.104 & 0.009 & 1.000 & \\
\hline & Model 2 & & & & & 2.101 \\
\hline & Window opening in winter (Ref.: No) & 0.048 & -0.092 & 0.021 & 1.028 & \\
\hline
\end{tabular}

Notes: Model I: unadjusted. Model 2: adjusted for sex, father's highest degree, mother's highest degree, allergic history, past history of respiratory diseases and family history of respiratory diseases. Bold values mean $\mathrm{P}<0.05$.

Abbreviations: FVC, forced vital capacity; $\mathrm{FEV}_{1}$, forced expiratory volume in I s; PEF, peak expiratory flow velocity; $\mathrm{V}_{75}$, forced expiratory flow at $75 \%$ FVC; $\mathrm{V}_{25}$, forced expiratory flow at $25 \% \mathrm{FVC}$; SE, standard error; VIF, variance inflation factor.

factors that affect pulmonary function indicators in children were nearly all indoor environmental factors. Appropriate reduction or elimination of these environmental risk factors could help reduce the effect of this risk. ${ }^{21,22}$

The detrimental effects of passive smoke exposure on pulmonary function are well documented. ${ }^{23,24}$ Our findings also further confirm that passive smoking is a significant environmental risk factor for respiratory disease and lung function in children. Additionally, rhinallergosis and tracheitis/bronchitis were influenced by passive smoking. This may be because environmental tobacco smoke may generate certain adverse effects on ciliary activity and the function of mucociliary cilia in the respiratory mucosa, leading to changes in some structures that may disrupt or weaken defense mechanisms. ${ }^{25}$ Mucus produced by secretory cells in 
the mucosa effectively protects the respiratory tract by clearing hazardous particles. ${ }^{26}$ As a result of the body's defense mechanisms, tobacco smoke may facilitate mucus production, but it may also alter the mucus glycoprotein content and reduce its viscoelasticity. ${ }^{27}$ Furthermore, submicron particles and nanoparticles are also responsible for the negative effect of PM on children's lung health. ${ }^{28}$

A study conducted in Italian children concluded that passive smoking was a trigger for asthma-like symptoms and increased $\mathrm{FEV}_{1} / \mathrm{FVC}$, which was different from our findings. ${ }^{29}$ In the multivariate results of pulmonary function indicators, only $\mathrm{FVC}$ and $\mathrm{FEV}_{1}$ were impacted by passive smoking in children, while passive smoking was not significantly associated with $\mathrm{FEV}_{1} / \mathrm{FVC}$. Passive smoking was found to reduce FVC and FEV1 in children, which was consistent with the study by Tager IB. ${ }^{30}$

Few studies have investigated the effects of insecticide use on respiratory disease in children, and a relatively novel finding of this study was that insecticide exposure was an independent risk factor for respiratory disease. After human exposure to insecticides occurs in the home, these substances can enter the body ${ }^{31,32}$ through the diet or respiratory tract and create physical harm. In contrast to the findings of Yang, ${ }^{33}$ we found that insecticide exposure could contribute to respiratory disease in children beyond just cough symptoms. An animal study ${ }^{34}$ suggested that exposure to some pesticides over time could be connected to diaphragmatic contractility and altered breathing patterns in rats. The lungs are not fully developed in children; therefore, they may be more susceptible to environmental toxins inhaled via the respiratory tract. ${ }^{35}$ Preventing children from the hazards of pesticide exposure should therefore be brought to the attention of parents.

Exposure to industrial pollutants could also interfere with recurrent respiratory tract infection. Garbage stations and foul ditches produce irritating gases through fermentation, ${ }^{36-38}$ and the combustion of garbage and the emission of pollutants from heating companies produce large amounts of polycyclic aromatic hydrocarbons (PAHs) and inhalable particulate matter (IPM) contents in the air. ${ }^{39}$ PAHs compromise the normal developmental process of respiratory airways; mutagenicity can activate the activity of PAHs, and they are associated with depressed lung function in children. ${ }^{40,41}$ Similarly, the IPM was more strongly associated with respiratory diseases. $^{42-44}$ In this study, we did not observe environmental risk factors for asthma or pneumonia, which may be due to the low prevalence of asthma and pneumonia (approximately 1\%).

Exposure to roadway air pollution adversely affected childhood lung function. In this study, the increase in distance from home to the main road adversely affected $\mathrm{FEV}_{1}$ /FVC, consistent with the findings of several studies, ${ }^{45,46}$ but may have the opposite association with FCV. Robert ${ }^{47}$ found that close proximity to a major road was negatively associated with FVC and FEV1, but these associations were not statistically significant. Therefore, the relationship between children's FVC, FEV1 and the distance from home to the main road still needs to be evaluated by more studies. It is desirable to detect each contaminant's concentration at different distances to analyze its relationship with the indicators of lung function in children.

Questionnaires facilitate access to larger sample sizes and are less limited by location and distance. When combined with electronic questionnaires and web-based reporting systems, ${ }^{48}$ they also allow for more comprehensive and accurate analysis by utilizing regional surveillance data. Our study has several advantages over previous studies, including (1) a large sample size, which made the results more reliable and allowed us to analyze a wide range of respiratory diseases; (2) detailed information about the environmental exposure factors and the selection of a subset for lung function measurements; and (3) new evidence for insecticide exposure as an indoor risk factor for respiratory disease in children. However, some limitations still exist in our study: (1) the cross-sectional design used in our research may have biased and limited the interpretation of causality; (2) environmental risk factors were determined by questionnaire rather than on-site exposure assessment; and (3) there may be some residual miscellaneous factors that were not captured on the questionnaire. Further studies for these additional risk factors, with detailed exposure assessments, are needed.

\section{Conclusions}

The primary risk factors differ among the different respiratory diseases. Passive smoking remains an essential adverse factor for respiratory disease and pulmonary function in children, and it is important to reduce exposure to passive smoking for children's pulmonary health. Insecticide exposure may be a neglected environmental risk factor, and further investigations are still needed to 
explore the relationship and mechanisms between insecticide exposure and children's respiratory health.

\section{Funding}

China's Central Government subsidizes projects to monitor the impact of local air pollution on people's health; Key Scientific Research Project of Jilin Provincial Health and Family Planning Commission in 2015 (2015Z03).

\section{Disclosure}

The authors declare that there are no conflicts of interest regarding the publication of this paper.

\section{References}

1. Prüss-üstün A, Wolf J, Corvalán C, Bos R, Neira M. Preventing Disease Through Healthy Environments: A Global Assessment of the Burden of Disease from Environmental Risks. World Health Organization; 2016.

2. Murray CJ, Aravkin AY, Zheng P, et al. Global burden of 87 risk factors in 204 countries and territories, 1990-2019: a systematic analysis for the Global Burden of Disease Study 2019. Lancet. 2020;396(10258):12231249.

3. Rojas-Rueda D, Vrijheid M, Robinson O, et al. Environmental burden of childhood disease in Europe. Int J Environ Res Public Health. 2019;16(6):1084. doi:10.3390/ijerph16061084

4. Kassebaum NJ, Arora M, Barber RM, et al. Global, regional, and national disability-adjusted life-years (DALYs) for 315 diseases and injuries and healthy life expectancy (HALE), 1990-2015: a systematic analysis for the Global Burden of Disease Study 2015. Lancet. 2016;388(10053):1603-1658.

5. Do DC, Zhao Y, Gao P. Cockroach allergen exposure and risk of asthma. Allergy. 2015;71(4):463-474. doi:10.1111/all.12827

6. Carrer P, Maroni M, Alcini D, Cavallo D. Allergens in indoor air: environmental assessment and health effects. Sci Total Environ. 2001;270(1-3):33-42. doi:10.1016/S0048-9697(00)00791-9

7. Sucharew H, Ryan PH, Bernstein D, et al. Exposure to traffic exhaust and night cough during early childhood: the CCAAPS birth cohort. Pediatr Allergy Immunol. 2010;21(2p1):253-259. doi:10.1111/ j.1399-3038.2009.00952.x

8. Zora JE, Sarnat SE, Raysoni AU, et al. Associations between urban air pollution and pediatric asthma control in El Paso, Texas. Sci Total Environ. 2013;448(6):56-65. doi:10.1016/j.scitotenv.2012.11.067

9. Rojasmartinez R, Perezpadilla R, Olaizfernandez G, et al. Lung function growth in children with long-term exposure to air pollutants in Mexico City. Am J Respir Crit Care Med. 2007;176(4):377. doi:10.1164/recm.200510-1678OC

10. Chen H, Goldberg MS, Villeneuve PJ. A systematic review of the relation between long-term exposure to ambient air pollution and chronic diseases. Rev Environ Health. 2008;23(4):243-298. doi:10.1515/reveh.2008.23.4.243

11. Schultz ES, Gruzieva O, Bellander T, et al. Traffic-related air pollution and lung function in children at 8 years of age: a birth cohort study. Am J Respir Crit Care Med. 2012;186(12):1286-1291. doi:10.1164/rccm.201206-1045OC

12. Jaakkola JJ, Knight TL. The role of exposure to phthalates from polyvinyl chloride products in the development of asthma and allergies: a systematic review and meta-analysis. Environ Health Perspect. 2008;116(7):845-853. doi:10.1289/ehp.10846

13. Bornehag CG, Nanberg E. Phthalate exposure and asthma in children. Int J Androl. 2010;33(2):333-345. doi:10.1111/j.1365-2605.2009.01023.x
14. Dong GH, Qian ZM, Wang J, et al. Home renovation, family history of atopy, and respiratory symptoms and asthma among children living in China. Am J Public Health. 2014;104(10):1920. doi:10.2105/ AJPH.2013.301438

15. Kanchongkittiphon W, Mendell MJ, Gaffin JM, Wang G, Phipatanakul W. Indoor environmental exposures and exacerbation of asthma: an update to the 2000 review by the institute of medicine. Environ Health Perspect. 2015;123(1):6. doi:10.1289/ehp.1307922

16. Lugade AA, Bogner PN, Thatcher TH, Sime PJ, Phipps RP, Thanavala Y. Cigarette smoke exposure exacerbates lung inflammation and compromises immunity to bacterial infection. J Immunol. 2014;192(11):5226. doi:10.4049/jimmunol.1302584

17. Ma YN, Qian Z, Wang J, et al. Environmental tobacco smoke exposure, urine CC-16 levels, and asthma outcomes among Chinese children. Allergy. 2015;70(3):295-301. doi:10.1111/all.12559

18. Magnus MC, Håberg SE, Karlstad Ø, Nafstad P, London SJ, Nystad W. Grandmother's smoking when pregnant with the mother and asthma in the grandchild: the Norwegian Mother and Child Cohort Study. Thorax. 2015;70(3):237-243. doi:10.1136/thoraxjnl2014-206438

19. Singh S, Sharma BB, Salvi S, et al. Allergic rhinitis, rhinoconjunctivitis, and eczema: prevalence and associated factors in children. Clin Respir J. 2018;12(2):547-556. doi:10.1111/crj.12561

20. Kim SY, Sim S, Choi HG. Active, passive, and electronic cigarette smoking is associated with asthma in adolescents. Sci Rep. 2017;7 (1):17789. doi:10.1038/s41598-017-17958-y

21. Crocker DD, Kinyota S, Dumitru GG, et al. Effectiveness of home-based, multi-trigger, multicomponent interventions with an environmental focus for reducing asthma morbidity: a community guide systematic review. Am J Prev Med. 2011;41(2):S5-32. doi:10.1016/j.amepre.2011.05.012

22. Dennekamp M, Howarth S, Dick CA, Cherrie JW, Donaldson K, Seaton A. Ultrafine particles and nitrogen oxides generated by gas and electric cooking. Occup Environ Med. 2001;58(8):511-516. doi:10.1136/oem.58.8.511

23. Wang L, Pinkerton KE. Detrimental effects of tobacco smoke exposure during development on postnatal lung function and asthma. Birth Defects Res C Embryo Today. 2008;84(1):54-60. doi:10.1002/ bdrc. 20114

24. Stocks J, Dezateux C. The effect of parental smoking on lung function and development during infancy. Respirology. 2003;8 (3):266-285. doi:10.1046/j.1440-1843.2003.00478.x

25. Elwany S, Ibrahim AA, Mandour Z, Talaat I. Effect of passive smoking on the ultrastructure of the nasal mucosa in children. Laryngoscope. 2012;122(5):965-969. doi:10.1002/lary.23246

26. Rogers DF, Jeffery PK. Inhibition of cigarette smoke-induced airway secretory cell hyperplasia by indomethacin, dexamethasone, prednisolone, or hydrocortisone in the rat. Exp Lung Res. 1986;10 (3):285-298. doi: $10.3109 / 01902148609061498$

27. Jeffery PK, Reid LM. The effect of tobacco smoke, with or without phenylmethyloxadiazole (PMO), on rat bronchial epithelium: a light and electron microscopic study. J Pathol. 1981;133(4):341-359. doi:10.1002/path.1711330406

28. Protano C, Manigrasso M, Avino P, Sernia S, Vitali M. Second-hand smoke exposure generated by new electronic devices (IQOS ${ }^{\circledR}$ and e-cigs) and traditional cigarettes: submicron particle behaviour in human respiratory system. Ann Ig. 2016;28(2):109-112. doi:10.7416/ai.2016.2089

29. Bellisario V, Piccioni P, Bugiani M, et al. Tobacco smoke exposure, urban and environmental factors as respiratory disease predictors in Italian adolescents. Int $J$ Environ Res Public Health. 2019;16 (20):4048. doi:10.3390/ijerph16204048

30. Tager IB, Weiss ST, Muñoz A, Rosner B, Speizer FE. Longitudinal study of the effects of maternal smoking on pulmonary function in children. $N$ Engl J Med. 1983;309(12):699-703. doi:10.1056/ NEJM198309223091204 
31. Nougadère A, Sirot V, Kadar A, et al. Total diet study on pesticide residues in France: levels in food as consumed and chronic dietary risk to consumers. Environ Int. 2012;45:135-150. doi:10.1016/j. envint.2012.02.001

32. Lu C, Barr DB, Pearson MA, Waller LA. Dietary intake and its contribution to longitudinal organophosphorus pesticide exposure in urban/suburban children. Environ Health Perspect. 2008;116 (4):537-542. doi:10.1289/ehp.10912

33. Yang CY, Chiu JF, Cheng MF, Lin MC. Effects of indoor environmental factors on respiratory health of children in a subtropical climate. Environ Res. 1997;75(1):49-55. doi:10.1006/enrs.1997.3774

34. Darwiche W, Gay-Quéheillard J, Delanaud S, et al. Impact of chronic exposure to the pesticide chlorpyrifos on respiratory parameters and sleep apnea in juvenile and adult rats. PLoS One. 2018;13(1): e0191237. doi:10.1371/journal.pone.0191237

35. Roy A, Hu W, Wei F, Korn L, Chapman RS, Zhang JJ. Ambient particulate matter and lung function growth in Chinese children. Epidemiology. 2012;23(3):464 472. doi:10.1097/EDE.0b013e31824cbd6d

36. Lee DY, Ebie Y, Xu KQ, Li YY, Inamori Y. Continuous H2 and $\mathrm{CH} 4$ production from high-solid food waste in the two-stage thermophilic fermentation process with the recirculation of digester sludge. Bioresour Technol. 2010;101(1):S42-S47. doi:10.1016/j.biortech.2009.03.037

37. Yokley B, Alyse K. Physiologically based model development and parameter estimation benzene dosimetry in humans and respiratory irritation response in rodents. Polish J Ecol. 2008;56(1):45-56.

38. Meulenbelt J. Irritant gases. Medicine. 2016;44(3):175-178. doi:10.1016/j.mpmed.2015.12.004

39. Chang SC, Chang KT, Keng YF, et al. Mutagenicity and polycyclic aromatic hydrocarbons analysis of airborne particulate matters from Taipei City. Proc Natl Sci Counc Repub China B. 1988;12(3):129.

40. Jedrychowski WA, Perera FP, Maugeri U, et al. Long term effects of prenatal and postnatal airborne PAH exposures on ventilatory lung function of non-asthmatic preadolescent children. Sci Total Environ. 2015;502(502C):502-509.

41. Umbuzeiro GA, Franco A, Martins MH, et al. Mutagenicity and DNA adduct formation of $\mathrm{PAH}$, nitro-PAH, and oxy-PAH fractions of atmospheric particulate matter from Sao Paulo, Brazil. Mutat Res Genet Toxicol Environ Mutagen. 2008;652(1):72-80. doi:10.1016/j. mrgentox.2007.12.007
42. Zhao WH, Gong HL, Zhao WJ, Tang T. Spatio-temporal variations of the distribution of urban inhalable particulate matter and its impact on respiratory diseases. Paper presented at: International Conference on Bioinformatics and Biomedical Engineering; Chengdu, China; 2010.

43. Tang J, Xia Y, Tang X, Dai H, Cheng S. Effect of inhalable particulate matter on respiratory system diseases in children sampled from different polluted areas in Chongqing. J Third Military Medl Univ. 2015.

44. Wenhui Z, Wenji Z, Huili G, Zhaoning G. Spatial and temporal distribution of inhalable particulate matters and the source tracing in the heating season of Beijing. Geogr Res. 2012;31(3):417-428.

45. Mentese S, Mirici NA, Otkun MT, et al. Association between respiratory health and indoor air pollution exposure in Canakkale, Turkey. Build Environ. 2015;93:72-83. doi:10.1016/j.buildenv.2015.01.023

46. Nuvolone D, Maggiore RD, Maio S, et al. Geographical information system and environmental epidemiology: a cross-sectional spatial analysis of the effects of traffic-related air pollution on population respiratory health. Environ Health. 2011;10(1):1-12. doi:10.1186/1476-069X-10-12

47. Urman R, Mcconnell R, Islam T, et al. Associations of children's lung function with ambient air pollution: joint effects of regional and nearroadway pollutants. Thorax. 2014;69(6):540. doi:10.1136/thoraxjnl-2012203159

48. Norbäck D, Lu C, Zhang Y, et al. Common cold among pre-school children in China - associations with ambient PM(10) and dampness, mould, cats, dogs, rats and cockroaches 410 in the home environment. Environ Int. 2017;103:13-22. doi:10.1016/j.envint.2017.03.015
Risk Management and Healthcare Policy

\section{Publish your work in this journal}

Risk Management and Healthcare Policy is an international, peerreviewed, open access journal focusing on all aspects of public health, policy, and preventative measures to promote good health and improve morbidity and mortality in the population. The journal welcomes submitted papers covering original research, basic science, clinical \& epidemiological studies, reviews and evaluations, guidelines, expert opinion and commentary, case reports and extended reports. The manuscript management system is completely online and includes a very quick and fair peer-review system, which is all easy to use. Visit http://www.dovepress.com/testimonials.php to read real quotes from published authors. 